\title{
Pengaruh Jumlah Sudu Prototype Pembangkit Listrik Tenaga Mikrohidro Tipe Whirlpool Terhadap Kinerja
}

\author{
K. Umurani ${ }^{1 *}$, A M Siregar ${ }^{2}$, dan Surya Al-Amin ${ }^{3}$ \\ ${ }^{1,2,3}$ Program Studi Teknik Mesin, Fakultas Teknik, Universitas Muhammadiyah Sumatera Utara \\ Email:* khairulumurani@umsu.ac.id
}

\begin{abstract}
The water turbine is a device that converts water flow energy into shaft mechanical energy. Before being converted into mechanical energy in the turbine, the potential energy needs to be converted into kinetic energy first. The vortex will move the turbine blades which cause the runner to rotate so that there is a change in the kinetic energy of the water into mechanical energy in the turbine which is used to drive the generator and then into electrical energy. The purpose of this research is to analyze the torque that occurs on the shaft and turbine power. Water is flowed to the test with a pump through a control valve. The water flow is read by a rotameter attached to the pipe to the upper reservoir, while the torque is measured using a load cell, while the rotation is measured using a photo sensor interrupt to read the movement of the counter wheel. Data from load cell and photo sensor interruptor is read using Arduino Uno then the data is stored on laptop in excel file using plx-daq software. The minimum torque for the 8 blades is $9,12 \mathrm{~kg} . \mathrm{mm}$ and $7.61 \mathrm{~kg} . \mathrm{mm}$ for 6 blades at a water flow rate of $90 \mathrm{l} / \mathrm{min}$. The maximum torque occurs at the 8 blades of 10.06 $\mathrm{kg} . \mathrm{mm}$ while the maximum torque at blade 6 is $9,12 \mathrm{~kg} . \mathrm{mm}$ at the same water flow rate of $150 \mathrm{l} /$ min. The minimum turbine power for the 8 blades is $0.47 \mathrm{~W}$ and $0.27 \mathrm{~W}$ for the 6 blades at a water flow rate of $90 \mathrm{l} / \mathrm{min}$. The maximum turbine power at blade 8 is $1.03 \mathrm{~W}$, while the maximum power at blade 6 is $0.91 \mathrm{~W}$ at the same water flow rate of $150 \mathrm{l} / \mathrm{min}$. From the data analysis, it can be seen that the power for the turbine with the number of blades 8 tends to be greater than the power for the turbine with 6 blades, but if the percentage increases in power between the 8 blades and 6 blades the trend decreases even though the flow rate is increasing.
\end{abstract}

Keywords: Number of blades, turbine power, whirlpool turbine performance

\section{PENDAHULUAN}

Listrik merupakan sumber energi yang digunakan oleh manusia. Listrik di hasilkan melalui sebuah sistem pembangkit listrik. Pembangkit yang banyak digunakan adalah pembangkit listrik tenaga air (PLTA), Pembangkit listrik tenaga gas bumi (PLTG), pembangkit listrik tenaga uap (PLTU), pembangkit listrik tenaga diesel (PLTD), dan pembangkit listrik tenaga nuklir (PLTN),PLTU dan PLTD menggunakan sumber energi berupa batubara ataupun minyak bumi.Pembangkit listrik yang menggunakan tenaga air sebagai media utama untuk penggerak turbin dan generator (PLMTH). Secara teknis, mikrohidro mempunyai tiga komponen utama yaitu air sumber energi turbin dan generator. Air mengalir dengan kapasitas tertentu disalurkan dengan ketinggian tertentu melalui pipa pesat menuju rumah instalasi (powerhouse).

Tekanan dan aliran air di dalam pipa dari pipa utamadari digunakan untuk kegiatan biasa dapat juga digunakan untuk memutar turbin mikro hidro menggerakkan generator untuk membangkitkan tenaga listriktelah dikebangkan. Dengan memanfaatpotensi energy yang terdapat pada pendistribusian air konsumsi yang ke rumah-rumahsebagai sumber energi listrik alternatif [1].

Turbin whirlpool dibuat oleh turbulent perusahaan belgia merupakan pembangkit listrik yang hampir dapat dipasang di semua kanal atau sungai memanfaatkan air yang mengalir untuk menghasilkan tenaga listrik bagi setidaknya 60 rumah sumber energi bersih yang juga ramah terhadap ikan ini dapat beroperasi pada siang dan malam hari. Turbin whirlpool ini memanfaatkan jeram kecil atau air terjun untuk mendapatkan energy. Sebidang tanah didekat sumber air digali 
untuk membuat sebuah bak dan saluran air kecil dengan konstruksi beton. Generator dan impeller dimasukan didalam bak lalu dinding sungai dibuka sedikit supaya sebagian air sungai bias masuk kedalamnya sehingga membuat turbin berputar. Putaran turbin ini menghasilkan energi tanpa batas sepanjang airnya mengalir.

Sudu adalah bagian dari turbin, dimana konversi energi terjadi sudu terdiri dari bagian akar sudu badan sudu dan ujung sudu kemudian di rangkai sehingga membentuk satu lingkaranpenuh.Komponen utama dalam penelitian ini adalah sudu tetapyang merupakan suatu kontruksi lempengan dengan bentuk dan penampang tertentu, Air sebagai fluida kerja mengalir melalui ruang diantara sudu tersebut, dengan deimikian roda turbin akan dapat berputar dan pada

Turbin air terdapat dalam suatu pembangkit listrik berfungsi untuk mengubah energi potensial yang dimiliki air menjadi energi kinetik. Selanjutnya energi kinetik ini akan dirubah menjadi energi elektrik melalui generator. Hal ini menyebabkan setiap pembahasan tentang turbin hidrolik akan mengikutsertakan generator sebagai pembangkit listrik.Turbin air adalah salah satu mesin penggerak yang mana fluida kerjanya adalah air.Berdasarkan perubahan energi turbin air dibedakan menjadi dua kelompok yaitu turbin Impuls dan turbin reaksi.Turbin air adalah suatu mesin berputar yang mengkonversikan energi suatu gerakan aliran air menjadi energi mekanis yaitu energi puntir. Energi mekanis ini kemudian ditransfer melalui suatu poros untuk mengoperasikan mesin atau generator[2]Aliran air masuk ketahap pertama melalui nozel, kemudian keluar ketahap kedua melewati ruang udara pusat. Tetapi tahap tidak mengubah semua energi yang tersedia menjadi kerja [3].Berdasarkan penelitian yang dilakukan

Profil sudu turbin yang berbentuk mangkuk memiliki karakteristik daya dan efesiensi yang lebih baik dari bentuk sudu setengah silender[4], Raharjo,2008 juga menyatakan profil sudu mangkuk lebih baik efisiensi dari pada profil sudu bilah sejajar, profil sudu bilah tegak lurus[5].

Kecepatan angular dan besarnya torsi sangat mempengaruhi daya turbin, massa aliran yang menumbuk sudu turbin menyebabkan kecepatan anguler yang akan mempengaruhi daya turbin dan efisiensi turbin. Hal ini dapat dilakukan dengan meningkatkan debit air yang menumbuk sudu turbin [6]

Pemilihan suatu turbin tergantung pada karakteristik lokasi, karena menentukan tinggi air jatuh dan kapasitas air. Selain itu pemilihan turbin juga tergantung dari kecepatan putar yang di minta oleh generator.

\section{Turbin whirlpool}

Turbin ini hanya memiliki satu komponen yang bergerak, sehingga umur teknisnya panjang dan tidak membutuhkan perawatan yang rumit. Sampah atau kotoran berukuran besar yang masuk dari sungai ditangkap oleh sebuah layar yang mampu membersihkan diri secara otomatis. Menurut turbulent, bak beton dapat bertahan hingga seratus tahun, turbinya pun tidak akan mengganggu kehidupan ikan-ikan yang ada di sungai.

Turbulent mengklaim bahwa seiring perjalanan waktu, pembangkit listrik tenaga air dengan bendungan dan turbin bertekanan tinggi yang semakin berkurang keberlanjutannya, dan tujuan adalah agar sumber energi dari airmenjadi berkelanjutan kembali.sudu ada gaya yang bekerja. Oleh karena itu sudu merupakan bagian yang sangat penting pada turbin.Berdasarkan uraian diatas maka penulis tertarik untuk melakukan penelitian dengan mengenaiprototype pembangkit listrik tenaga mikrohidro tipe whilpool terhadap torsi dan daya yang dihasilkanDengan melihat bagaimana pengaruh jumlah sudu prototype pembangkit listrik tenaga mikrohidro tipe whilpool terhadap daya yang dihasilkan Adapun tujuan dalam penelitian ini adalahuntuk mengetahui pengaruh jumlah terhadap daya air yang di hasilkan oleh prototype turbin whirlpool skala laboratorium. Dalam penelitian ini peneliti melakukan penelitian dengan dua kelompok jumlah sudu yaitu 6 dan 8 buah sudu yang akan diuji untuk mendapatkan informasi-imformasi mengenai torsi dan daya turbin whirpool.

Besarnya torsi dapat dihitung dengan persamaan: 
Daya turbin dihitung dengan persamaan:

$$
P_{t}=\frac{(T / 1000)(2 \pi n / 60)}{102} \quad(k W)
$$

\section{METODE}

Pelaksaan dalam menyelesaikan penelitian ini prototype pembangkit listrik tenaga mikrohidro tipe whirlpool di Laboratorium Teknik Mesin Universitas Muhammadiyah Sumatera Utara.

Adapun test rig yang digunakan dalam penelitian ini seperti pada Gambar 6:

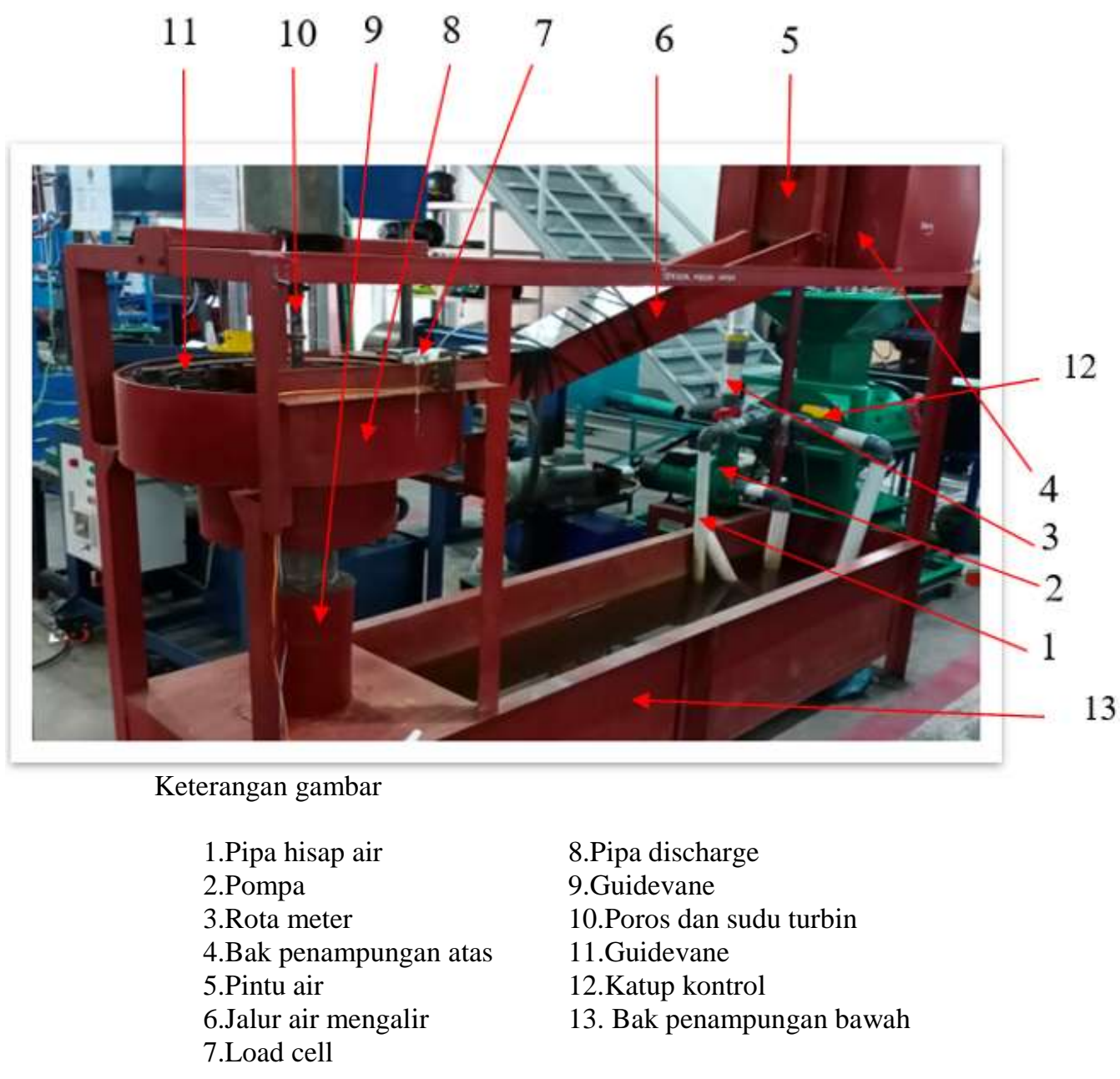

Gambar 1. Test rig pengujian

\section{Alat dan bahan}

Alat yang digunakan dalam prosedur pengujian pengaruh jumlah sudu 6 dan sudu 8 


\section{Jurnal Rekayasa Material, Manufaktur dan Energi}

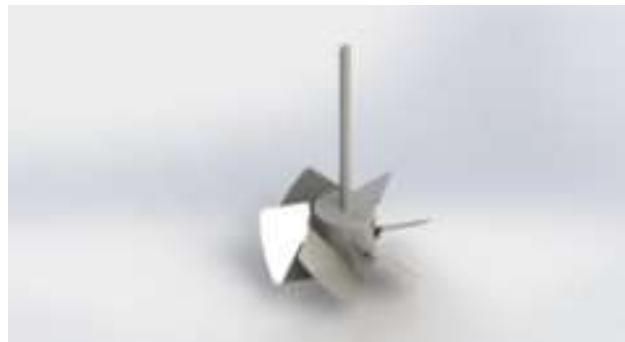

(a)sudu dengan 6 buah bilah

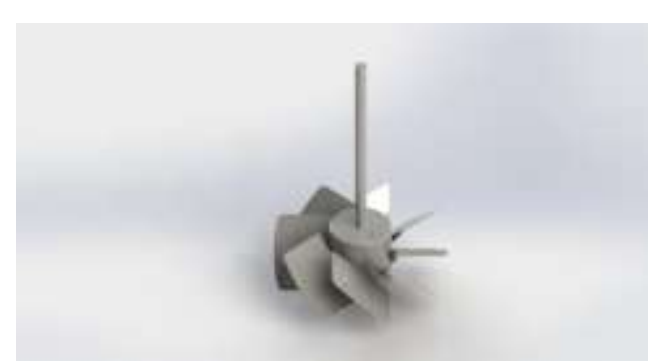

b)sudu dengan 8 buah bilah

Gambar 2. Sudu turbin yang akan dilakukan pengujian

\section{Mikrokontrol Arduino}

Mikrokontrol arduino uno Gambar 8 digunakan untuk mengontrol dan menerjemahkan data ataupun input sinyal yang ditangkap oleh sensor pembaca seperti sensor putaran poros dan gaya pengermana pada poros akan terbaca pada load cell dan menerjemahkannya dalam bentuk data yang dapat dibaca secara visual.

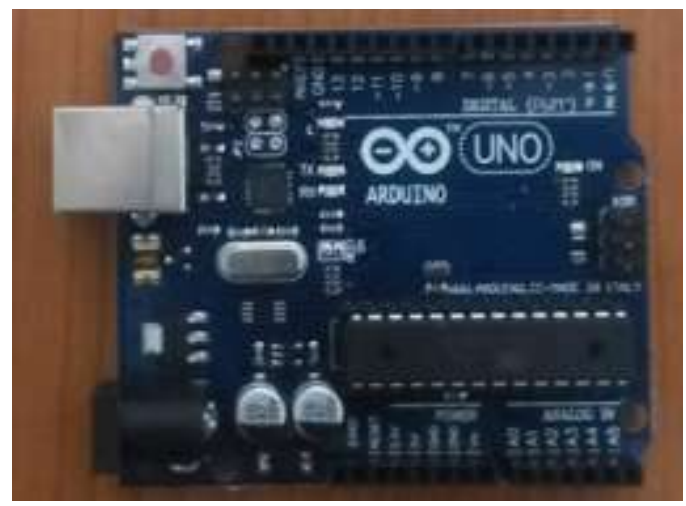

Gambar 3. Arduino Uno

\section{Photo SensorInteruptor}

Photo SensorInteruptor Gambar 9 ini berfungsi sebagai pembaca jumlah putaran poros turbin dengan sinar infra merah, data hasil pembacaan putaran akan di terjemahkan dalam bentuk data visual oleh arduino menggunakan serangkaian program.

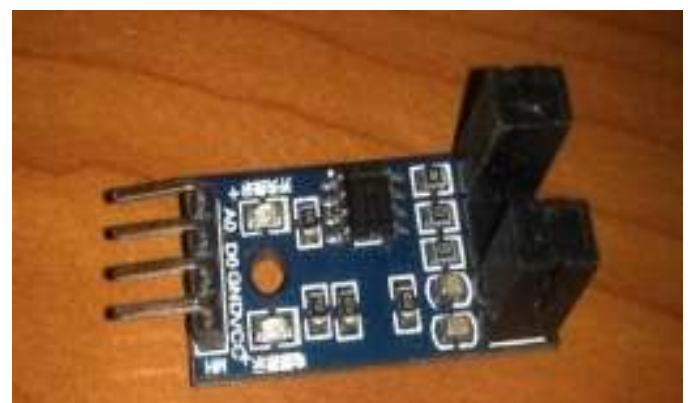

Gambar 4. Photo sensor interuptor

\section{Loadcell}

Load cell Gambar 10berfungsi sebagai pembaca berat beban yang diletakkan diatas poros turbin sebagai pengujian untuk mengetahui torsi yang terjadi pada poros. Load cell yang digunakan adalah load cell $5 \mathrm{Kg}$. 


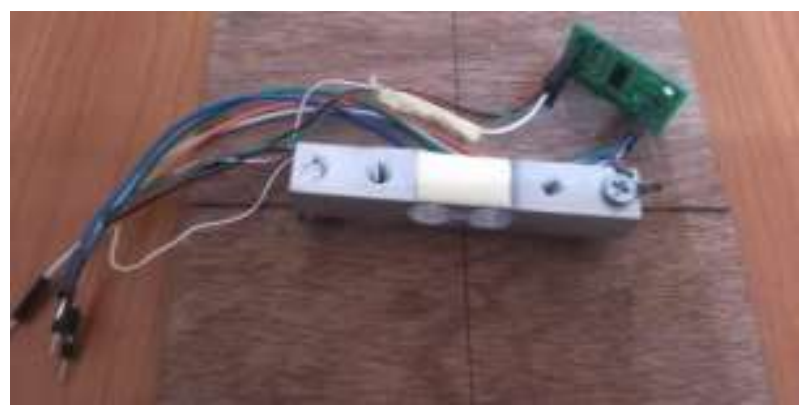

Gambar 5. Load Cell

\section{Pulley}

Pulley Gambar 11 berfungsi sebagai tempat sabuk penggantung beban, beban yang di ikat menggunakan tali yang digantung di pulley yang berguna untuk mengukur gaya torsi.

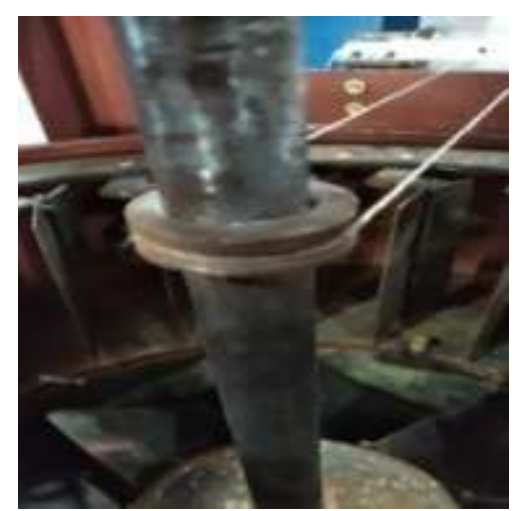

Gambar 6. Pulley

\section{Roda Pencacah}

Roda pencacah Gambar 12 diletakkan dicelah-celah antara sensor putaran, roda ini berfungsi untuk mempengaruhi intensitas cahaya yang diberikan oleh sinar LED pada optocouler ke photo transistor yang akan memberikan perubahan level logika sesuai dengan putaran roda cacah.

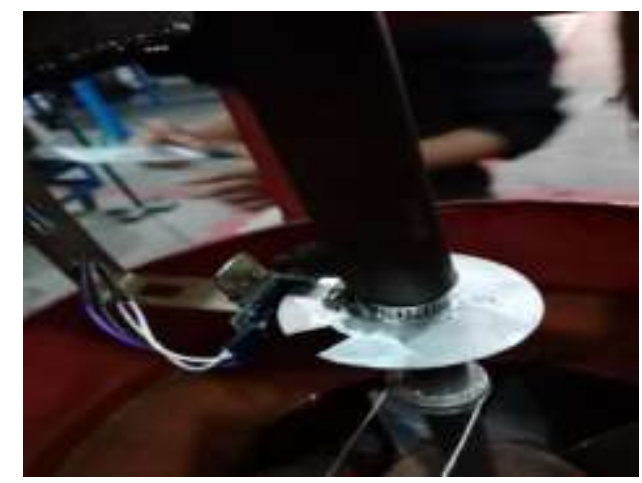

Gambar 7.. Roda Pencacah

\section{PLX-DAQ}

PLX-DAQ adalah free software yang digunakan untuk mencatat data serial di Microsoft exel yang dikirim oleh arduino uno kekomputer. 


\section{Jurnal Rekayasa Material, Manufaktur dan Energi}

\section{Prosedur Pengujian}

Langkah-langkah yang dilakukan dalam melakukan prosedur pengujian prototype turbin whirpool ini adalah sebagai berikut:

Langkah Persiapan

1. Mempersiapkan bahan dan alat untuk proses pengujian.

2. Mengisi bak air pada bak penampungan.

3. Merangkai dan menghubungkan sensor putar serta load cell padaarduino.

4. Memasang roda pencacah tepat diantara celah sensorputar.

5. Memberikan daya ke arduino dengan cara menghubungkan arduino ke laptop ataukomputer.

6. Memasang beban pemberat disertai load cell sebagai pembaca berat kepulley.

7. Menghidukan pompa air dan melakukkan pengamatan data yang ditampilkan dikomputer.

8. Pengujian diamati dengan pengaruh jumlah sudu 8 dan 6 dan lima variasi debit air dengan beban yang tetap pada loadcell.

\section{Pengukuran dan pengambilan data}

Pengukuran besaran-besaran penelitian dilakukan setelah perakitan dan pemasangan peralatan pengujian telah selesai dilakukan. Kemudian buka katup pengontrol aliran (12) kemudian hidupkan pompa (2) untuk mengalirkan air menuju kebak penampungan atas kemudian hidupkan pompa tunggu air tingginya sudah mencapai $75 \%$ air sudah mengisi bak penampungan atas (4) buka pintu air (5) kemudian atur ketinggian air dengan membuka atau menutup katup control (12). Kemudian catat laju aliran air dengan membaca skala yang tertera pada rotameter (3) kemudian berikan beban pada loadcell (7) sebesar 200 gram.Setelah air sudah megalir dengan stabil data dapat di rekam dilaptop dengan menggunakan PLX DAQ Lakukan langkah diatas dengan laju aliran air yang mulai dari 90,110,125,135,150 liter permenit untukjumlah sudu(6 dan 8). Daya turbin tiap-tiap jumlah sudu adalah dengan cara membaca pergerakan pertambahan beban yang terjadi setelah turbin berputar. Sebelum turbin berputar beban dihitung dulu berat awalnya.kemudian setalah turbin berputar catat pertambahan berat beban.Dan lakukan pengamatan kecepatan putar turbin saat porosberputar.Untuk menganalisa Torsi, daya turbin, daya air menggunakan persamaan $1,2,3$.

\section{Hasil dan pembahasan}

Daya sangat tergantung pada besarnya torsi dan putaran. Besaran torsi berbanding berbalik dengan putaran turbin debit air juga sangat berpengaruh terhadap torsi dan putaran, semakin besar debit yang diberikan akan menaikan daya suatu turbin. Dari hasil penelitian dan pengolahan data, maka didapat suatu perhitungan nilai torsi dengan debit air 90 liter/menit,110 liter/menit,125 liter/menit, 135 liter/menit, 150 liter/menit.dan memberi perbandingan dengan pengaruh jumlah sudu 6 dan jumlah sudu 8 dengan debit air yang sama.

Hasil pengujian turbin whirlpool dengan jumlah sudu 6 dan 8 sudu seperti data pada tabel berikut

Tabel 1.Hasil pengujian turbin dengan 6 buah sudu

\begin{tabular}{cccccc}
\hline $\begin{array}{c}\text { Debit Air } \\
(\mathbf{Q})(\mathbf{L} / \mathbf{m i n})\end{array}$ & $\begin{array}{c}\text { Gaya Berat } \\
(\mathbf{F})(\mathbf{g r})\end{array}$ & $\begin{array}{c}\text { Putaran } \\
(\mathbf{R p m})\end{array}$ & $\begin{array}{c}\text { Jari-jari } \\
(\mathbf{r})(\mathbf{m m})\end{array}$ & $\begin{array}{c}\text { Head } \\
(\mathbf{H})(\mathbf{m})\end{array}$ & $\begin{array}{c}\text { Beban } \\
(\mathbf{g r})\end{array}$ \\
\hline 90 & 543,47 & 34 & 14 & 1,24 & 200 \\
110 & 548,33 & 53 & 14 & 1,24 & 200 \\
125 & 573,20 & 86 & 14 & 1,24 & 200 \\
135 & 652,08 & 91 & 14 & 1,24 & 200 \\
150 & 651,12 & 97 & 14 & 1,24 & 200 \\
\hline
\end{tabular}

Tabel 2.Hasil pengujian turbin dengan 8 buah sudu

\begin{tabular}{cccccc}
\hline $\begin{array}{c}\text { Debit Air } \\
(\mathbf{Q})(\mathbf{L} / \mathbf{m i n})\end{array}$ & $\begin{array}{c}\text { Gaya Berat } \\
(\mathbf{F})(\mathbf{g r})\end{array}$ & $\begin{array}{c}\text { Putaran } \\
(\mathbf{R p m})\end{array}$ & $\begin{array}{c}\text { Jari-jari } \\
(\mathbf{r})(\mathbf{m m})\end{array}$ & $\begin{array}{c}\text { Head } \\
(\mathbf{H})(\mathbf{m})\end{array}$ & $\begin{array}{c}\text { Beban } \\
(\mathbf{g r})\end{array}$ \\
\hline 90 & 651,33 & 50 & 14 & 1,24 & 200 \\
110 & 658,19 & 82 & 14 & 1,24 & 200
\end{tabular}

Copyright $^{\circledR} 2020$ Jurnal Rekayasa Material, Manufaktur dan Energi. This is an open acces article under the CC-BY-SA lisence (https://creativecommons.org/licenses/by-sa/4.0/). 


\begin{tabular}{cccccc}
\hline $\begin{array}{c}\text { Debit Air } \\
(\mathbf{Q})(\mathbf{L} / \mathbf{m i n})\end{array}$ & $\begin{array}{c}\text { Gaya Berat } \\
(\mathbf{F})(\mathbf{g r})\end{array}$ & $\begin{array}{c}\text { Putaran } \\
(\mathbf{R p m})\end{array}$ & $\begin{array}{c}\text { Jari-jari } \\
(\mathbf{r})(\mathbf{m m})\end{array}$ & $\begin{array}{c}\text { Head } \\
(\mathbf{H})(\mathbf{m})\end{array}$ & $\begin{array}{c}\text { Beban } \\
(\mathbf{g r})\end{array}$ \\
\hline 125 & 622,58 & 97 & 14 & 1,24 & 200 \\
135 & 669,22 & 96 & 14 & 1,24 & 200 \\
150 & 718,58 & 100 & 14 & 1,24 & 200 \\
\hline
\end{tabular}

\section{Perbandingan torsi terhadap debit air pada jumlah sudu 6 dan 8}

Dari perbandingan antara torsi sudu 6 dan torsi sudu 8 dapat dilihat pada Gambar 13 bahwa pada debit air sebesar 90 l/min torsi yang dihasilkan oleh turbin dengan 6 bilan sudu sebesar 7,61 kg.mm untuk turbin dengan jumlah bilah sudu 8 torsi yang dihasilkan sebesar 9,12 kg.mm terlihat torsi pada jumlah sudu 8 lebih besar 19,8\% dibandingkan torsi yang dihasilkan turbin 6 buah sudu. Untuk debit air sebesar 110 1/min torsi pada turbin dengan jumlah sudu 6 buah adalah sebesar 7,68 kg.mm sedang untuk sudu 8 torsi yang dihasilkan adalah 9,21 kg.mm atau $20 \%$ lebih tinggi dibandingkan turbin dengan 6 buah sudu

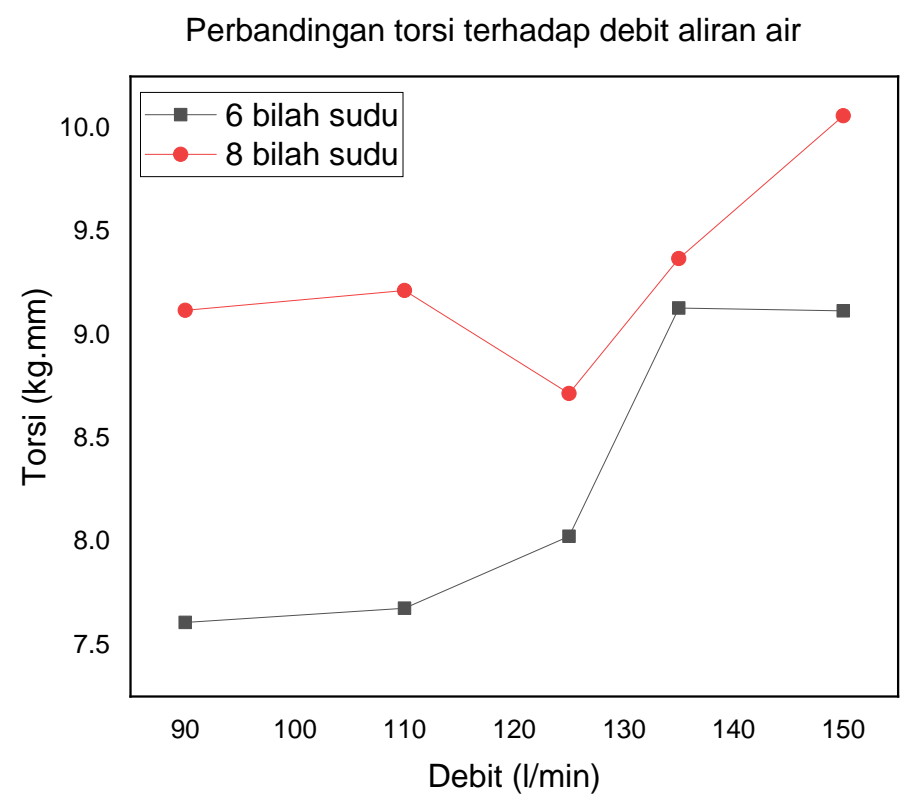

Gambar 8. Perbandingan torsi sudu 6 dan torsi sudu 8

Untuk debit $125 \mathrm{l} / \mathrm{min}$ torsi yang dihasilkan oleh turbin dengan jumlah sudu 6 buah adalah sebesar $8,02 \mathrm{~kg} . \mathrm{mm}$ sedangkan untuk sudu 8 buah torsi yang dihasilkan sebesar $8,71 \mathrm{~kg} . \mathrm{mm}$ dengan demikian torsi untuk sudu 8 buah 8,6\% lebih tinggi dari torsi turbin dengan 6 buah sudu. Untuk aliran air 135 1/min torsi yang dihasilkan oleh turbin dengan sudu 6 buah adalah sebesar 9,13 kg.mm sedangkan untuk torsi yang dihasilkan oleh turbin dengan sudu 8 buah adalah sebesar 9,37 kg.mm 2,6\% lebih tinggi dibandingkan dengan sudu 6 buah.Pada kapasitas alran air 150 l/min torsi yang dihasilkan oleh turbin dengan 6 buah sudu adalah sebesar 9,12 kg.mm sedangkan untuk turbin dengan 8 buah sudu adalah sebesar 10,06 kg.mm atau 10,3\% lebih tinggi dibandingkan torsi yang dihasilkan oleh turbin dengan 6 buah sudu.Torsi yang paling tinggi di dapat pada jumlah sudu 8 yaitu pada debit 150 1/min 10,10 kg.mm, sedangkan torsi yang paling rendah di dapat pada jumlah sudu 6 yaitu pada debit 90 l/min 7,61 kg.mmkarna pada debit 150 liter/menit pada sudu 8 aliran air sangat kencang saat menuju sudu turbin. pada alat penelitian ini memiliki diameter rumah sudu turbin kecil, mengakibatkan apabila air terlalu banyak masuk pada turbin maka tidak akan terjadi pusaran air yang sempurna dan apabila pusaran air sempurna maka torsi yang di dapat semakin tinggi.Dari Gambar 13 terlihat tren torsi untuk jumlah sudu 6 dan 8 terlihat meningkat hal ini sesuai

Copyright $^{\circledR} 2020$ Jurnal Rekayasa Material, Manufaktur dan Energi. This is an open acces article under the CC-BY-SA lisence (https://creativecommons.org/licenses/by-sa/4.0/). 
dengan penelitian Muliawa A. dan Yani A.,2016 [6] hanya pada sudu delapan tren sedikit menurun pada laju aliran $125 \mathrm{l} / \mathrm{min}$.

\section{Perbandingan daya terhadap debit air pada jumlah sudu 6 dan 8}

Perbandingan antara daya turbin sudu 6 dan daya turbin sudu 8 dapat dilihat pada Gambar 14. Dari Gambar 14 terlihat bahwa tren daya turbin cenderung meningkat seiring meningkatnya lau aliran air. Daya turbin pada laju aliran 90 1/min untuk sudu 8 adalah $0,47 \mathrm{~W}$ dan sudu 6 adalah 0,27 W terlihat bahwasanya pada laju aliran $90 \mathrm{l} / \mathrm{min}$ daya sudu 8 lebih tinggi 76, 24\% dari sudu 6 buah. Untuk aliran 110 1/min daya turbin dengan 8 buah sudu adalah $0,78 \mathrm{~W}$ sedangkan untuk sudu 6 daya turbin adalah 0,42 Watt. Dari data terlihat daya untuk sudu 8 lebih besar $85,72 \%$ dari daya turbin dengan sudu 6 buah. Untuk aliran 125 l/min daya turbin dengan sudu 8 adalah sebesar 0,87 Watt sedang untuk sudu 6 buah daya turbin adalah 0,71 Watt dengan demikian bahwa daya turbin untuk sudu 8 lebih besar dari sudu 6 sebesar 22,51\%. Untuk aliran air sebesar 135 1/min daya turbin dengan 8 sudu adalah sebesar 0,92 Watt sedang daya turbin dengan 6 buah sudu sebesar 0,85 Watt.

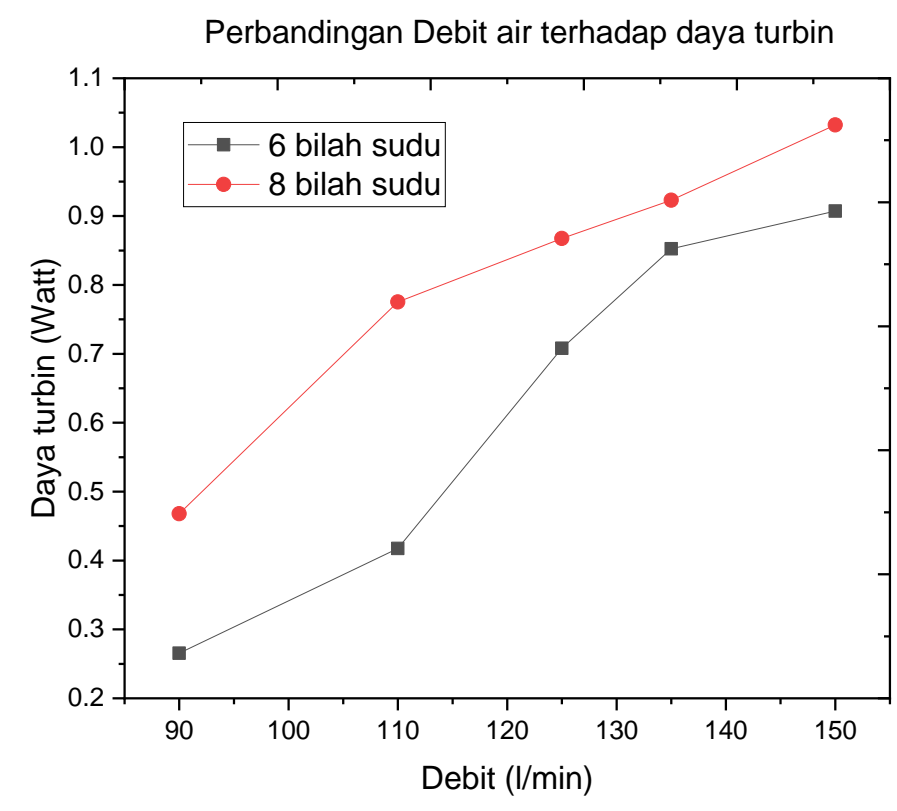

Gambar 14 Perbandingan daya turbin sudu 6 dan sudu 8

Terlihat bahwasanya daya turbin dengan 8 buah sudu 8,35 lebih tinggi dariturbin dengan 6 buah sudu. Untuk laju aliran $150 \mathrm{l} / \mathrm{min}$ daya turbin dengan 8 buah sudu adalah sebesar $103 \mathrm{Watt}$ sedang turbin dengan sudu 6 daya yang dihasilkan adalah sebesar 0,91 Watt. Terlihat bahwasanya daya turbin dengan sudu 8 dayanya lebih besar, 13,77\% dari sudu dengan 6 buah sudu. Daya yang paling besar di dapat pada daya turbin jumlah sudu 8 setiap daya turbin pada debit $150 \mathrm{~L} / \mathrm{m}=1,03$ Watt, sedangkan daya turbin yang paling rendah pada jumlah sudu 6 debit $90 \mathrm{l} / \mathrm{m}=0,2654549$ Watt. Dari data terlihat daya untuk turbin dengan jumlah sudu 8 cenderung lebih besar dibanding dengan daya turbin dengan sudu 6 buah akan tetapi jika dalam persentase kenaikan daya terlihat trennya menurun.

\section{KESIMPULAN}

Dari analisa hasil penelitian turbin whirlpool yang menggunakan jumlah sudu 6 dan sudu 8 dengan debit air 90 liter/menit, 110 liter/menit, 125 liter/menit, 135 liter/menit, dan 150 liter/menit yang tertera dilampiran dapat disimpulkan yaitu: 
1) Pada kesimpulan ini didapat bahwa Torsi yang terendah terdapat pada jumlah sudu 6 dengan debit 90 liter/menit dengan nilai Torsi $=7,60858 \mathrm{~kg} . \mathrm{mm}$ dan Torsi yang tertinggi didapat pada sudu 8 dengan debit 150 liter/menit dengan nilai Torsi=10,06572 kg.mm.

2) Daya turbin yang terendah terdapat pada sudu 6 pada debit 90 liter/menit dengan nilai= 0,2654549 watt dan daya turbin yang tertingi terdapat pada jumlah sudu 8 dengan debit 150 liter/menit dengan nilai $=1,03288761$ watt.

3) Daya air yang terendah terdapat pada jumlah sudu 6 dengan debit 90 liter/menit dengan nilai $=18,2466$ watt dan Daya air yang tertinggi terdapat pada jumlah sudu 8 dengan debit 150 liter/menit dengan nilai $=30,411$ watt

\section{DAFTAR PUSTAKA}

[1] H. Zainuddin, M. S. Yahaya, J. M. Lazi, M. F. M. Basar and Z. Ibrahim,2009, Design and Development of Pico-hydro Generation System for Energy Storage Using Consuming Water Distributed to Houses, International Journal of Electrical, Computer, Energetic, Electronic and Communication

[2] Paish, O. Small hydro power: Technology and current status. Renew. Sustain. Energy Rev. 2002, 6, 537-556

[3] Choi, Y.D.; Lim, J.I.; Kim, Y.T.; Lee, Y.H. Performance and internal flow characteristics of a cross-flow hydro turbine by the shapes of nozzle and runner blade. J. Fluid Sci. Technol. 2008, 3, 398-409.

[4] Bono dan Indarto. 2008. Karakterisasi daya turbin Pelton mikro dengan variasi bentuk sudu. Seminar Nasional Aplikasi Sains dan Teknologi 2008 - IST AKPRIND Yogyakarta.

[5] Raharjo T. 2008. Pengaruh variasi profil sudu pada runner terhadap efisiensi yang dihasilkan oleh turbin air pelton. Seminar Nasional Aplikasi Sains dan Teknologi 2008-Semarang

[6] A M Siregar, and C A Siregar 2019, Reliability test prototype wind turbine savonius type helical as an alternative electricity generator, The 2nd International Conference on Engineering and Applied Technolog, IOP Conf. Series: Materials Science and Engineering 674 (2019) 012059

[7] Muliawan A., Yani A.,2016,Analisis daya dan efisiensi turbin air kinetis akibat perubahan putaran runner Journal of Sainstek, 8(1): 1-9. 